\title{
Effects of Fertiliser Practices on the Growth and Quality of Two Table Grape Cultivars: 'Cardinal' and 'D. Maria'.
}

\author{
I. Domingos, ${ }^{1}$; T. Silva, ${ }^{2}$; P.J. Correia, ${ }^{1}$; M. Pestana ${ }^{1}$ and A. de Varennes ${ }^{3}$ \\ ${ }^{1}$ Universidade do Algarve, ${ }^{2}$ AVA, \\ FERN, \\ Campus de Gambelas \\ 8005-139 Faro \\ Portugal \\ Av. M $^{\mathrm{a}}$ Lizardo Palermo, \\ ${ }^{3}$ Instituto Superior de \\ Moncarapacho \\ 8700-081 Olhão \\ Portugal \\ Agronomia, DQAA, \\ Tapada da Ajuda \\ 1349-017 Lisboa, \\ Portugal
}

Keywords: fertilisation, nutritional status, quality, table grapes

\begin{abstract}
In this study, the different fertiliser practices of four commercial vineyards (Vitis vinifera L. cv. 'Cardinal' and cv. 'D. Maria') in southern Portugal were assessed and compared in 2002 . The vineyards were established in similar soils under the same climatic conditions and additional water was supplied by drip irrigation. At harvest, the mineral composition of petioles $(\mathrm{P}, \mathrm{K}, \mathrm{Mg}, \mathrm{Ca}, \mathrm{Fe}, \mathrm{Cu}, \mathrm{Zn}$ and $\mathrm{Mn}$ ) and quality parameters of the grapes (total soluble solids expressed as degree Brix, cluster length and weight, number of grapes, grapes weight and rachis weight) were recorded. For the 'Cardinal' cultivar, the nutritional status of the plant was correlated with growth and yield, and the greatest values for most of the parameters studied were measured at Alvisquer farm. For the 'D. Maria' cultivar, a single correlation was found between nutrient levels and growth. Shoot and cluster lengths, and grape weight were similar at all farms, though cluster weight, number of grapes and total soluble solids were smaller at Pedras than at Alvisquer or Gomeira.
\end{abstract}

\section{INTRODUCTION}

There are about 10 million hectares of vineyards in the world, most of which (80 $\%)$ producing grapes for wine. They are located on various types of soils in zones with Mediterranean, temperate or sub-tropical climates. Table grapes make an important contribution to the agriculture in southern Portugal, representing 30\% of the total vineyard production (G.P.P.A.A., 2001), but there is little information on the relationships between nutrients, yield and quality in these cultivars. The climatic conditions of this region - mild winters together with high temperatures and radiation in the growing season - encourage the production of table grapes. In recent years, farmers began to implement fertigation programmes, because the application of nutrients through irrigation water allows for flexible fertiliser programmes with correct amounts of nutrients applied at appropriate times. Excessive fertilisation may increase ground water pollution and labour costs, and particularly for $\mathrm{N}$ results in soft weedy growth and bad colouration of the grapes. Though recommendations for the fertilisation of vineyards are available (INIA, 2000 ), there is a wide range of fertiliser programmes in use among farmers.

The objective of this work was to evaluate the effects of different fertiliser practices on growth, yield, nutritional status, and quality of two representative cultivars of table grapes ('D. Maria' and 'Cardinal') in southern Portugal.

\section{MATERIALS AND METHODS}

Four different farms ("Gomeira"; "Alvisquer"; "Cascalhão" and "Pedras") located in the Tavira region in southern Portugal, were selected to evaluate the effects of fertiliser practices on the growth and fruit quality of two cultivars of table grapes (Vitis vinifera L. cv. 'D. Maria' and cv. 'Cardinal'). The farms were in the same vicinity, and all the vineyards were on south-facing slopes. The field trial was carried out during 2002 between March 14 and July 4 for 'Cardinal' cultivar and between March 21 and August 13 for 'D. Maria' cultivar. 
All the farms were located in limestone soils, low in organic matter. Soil samples were collected from $20-50 \mathrm{~cm}$ depth, mixed and a composite soil sample was oven-dried for 48 hours at $30{ }^{\circ} \mathrm{C}$ and passed through a $2-\mathrm{mm}$ sieve. Soils were analysed for $\mathrm{pH}$, and contents of $\mathrm{P}, \mathrm{K}$, and organic matter (Table 1). Potassium $(\mathrm{K})$ and phosphorus $(\mathrm{P})$ were extracted using a solution of ammonium lactate and acetic acid (Riehm, 1958). The $\mathrm{P}$ content in the extracts was quantified colorimetrically, and $\mathrm{K}$ by flame photometry (Isaac and Kerber, 1971). Soil $\mathrm{pH}$ was determined in a soil-water suspension (1:2.5), and soil organic matter content by the method of Walkley and Black (1934).

Hot and dry summers and mild winter characterize the climate of this region. The canopy structure on the trellises used in all farms was two sided and the details for each vineyard are presented in Table 2 .

The amounts of NPK applied, the number of applications and the duration of the fertigation period were different for each farm. The main NPK application was made during the winter (2001) in all farms; in Gomeira it was in the form of a commercial organic fertiliser $\left(400 \mathrm{~kg} \mathrm{ha}^{-1}\right)$ and at the other farms mineral fertiliser was used. Table 3 shows the total amounts of NPK applied throughout the year, including winter application. At Alvisquer farm, both cultivars received the greatest amounts of NPK spread over more fertigation episodes than at other farms. At Cascalhão and Pedras fertigation took place over a longer period of time.

Plants were drip irrigated, but this practice also differed between farms. The amounts of water applied were greatest in Alvisquer, while in Gomeira water supply was reduced during the maturation period.

At the Gomeira farm no micronutrients were applied. In contrast, 'Cardinal' vines from Cascalhão received 81 and $52 \mathrm{~g} \mathrm{ha}^{-1}$ respectively of $\mathrm{Fe}$ and $\mathrm{B}$, and at Alvisquer this cultivar received $24 \mathrm{~g} \mathrm{Fe} \mathrm{ha}^{-1}$ and $28 \mathrm{~g} \mathrm{~B} \mathrm{ha}^{-1}$. For the 'D. Maria' cultivar, the amounts of Fe and B applied were $45 \mathrm{~g} \mathrm{ha}^{-1}$ and $52 \mathrm{~g} \mathrm{ha}^{-1}$ in Pedras, and $24 \mathrm{~g} \mathrm{ha}^{-1}$ and $28 \mathrm{~g} \mathrm{ha}^{-1}$ in Alvisquer, respectively. The Fe foliar applications were made as a chelate (Fe-EDDHA), after the appearance of visual symptoms of iron chlorosis.

In each vineyard, 15 vines of each cultivar, randomly distributed in 5 rows, were selected. In 5 of the selected vines, the total shoot length was recorded during the experimental period. At the end of the growing cycle several fruit quality parameters were measured for 15 clusters: cluster length and weight, the number of grapes per cluster, fresh weight of the grapes, rachis weight and total soluble solids in juice (expressed as degrees Brix). Fruit quality parameters were determined according to standard methods (A.O.A.C., 1990). On the same occasion, mature leaves were collected in all the selected vines. The petioles were removed and washed with tap water, followed by distilled water containing a non-ionic detergent, then with $10 \mathrm{mmol} \mathrm{HCl} \mathrm{dm}{ }^{-3}$ and finally three rinses with distilled water. Petioles were dried at $60{ }^{\circ} \mathrm{C}$ for $48 \mathrm{~h}$, ground, ashed at $450{ }^{\circ} \mathrm{C}$, and digested in $10 \mathrm{~cm}^{3} \mathrm{HCl} 1 \mathrm{~mol} \mathrm{dm}$. Standardized procedures (A.O.A.C., 1990) were used to measure nutrient concentrations. Phosphorus was determined colorimetrically by the molybdo-vanadate method, and $\mathrm{K}, \mathrm{Mg}, \mathrm{Ca}, \mathrm{Fe}, \mathrm{Mn}, \mathrm{Cu}$ and $\mathrm{Zn}$ were measured by atomic absorption spectrometry. The dry weight of the petioles was also recorded.

Differences between fertiliser practices (source of variation) were evaluated by one-way analysis of variance, and means were compared using the Duncan multiple range test at $\mathrm{p}<0.05$. For each cultivar, correlations were established between the concentrations of each nutrient and clusters quality parameters.

\section{RESULTS}

There were no deficiency symptoms apparent in cv. 'D. Maria' at any farm, but 'Cardinal' vines showed iron chlorosis. Foliar sprays corrected this deficiency at Alvisquer but at Cascalhão the symptoms were visible until at the end of the season in spite of the foliar applications of Fe.

For the cultivar 'Cardinal', shoot growth was significantly greater at Gomeira than on the other farms, but no differences between farms were observed for ' $D$. Maria' cultivar (Figure 1). Petioles of 'Cardinal' cultivar had similar dry weights but at Gomeira, 
the petioles of cultivar 'D. Maria' had the greatest dry weight (Table 4). For 'Cardinal' cultivar, the concentrations of $\mathrm{Mg}, \mathrm{Ca}, \mathrm{Fe}$ and $\mathrm{Mn}$ in petioles were significantly greater at Alvisquer than on the other farms, but the opposite was true for $\mathrm{P}$. The greatest value of $\mathrm{P}$ was registered at Gomeira. No differences were observed for $\mathrm{Zn}$ and $\mathrm{Cu}$ concentrations (Table 4). For 'D. Maria' cultivar, Mn and Zn concentrations were greater at Alvisquer than on the other farms. The $\mathrm{Ca}$ concentration was greater at Alvisquer and Gomeira farms. Pedras had the greatest values of $\mathrm{P}$ and $\mathrm{Mg}$. The $\mathrm{K}$ and $\mathrm{Cu}$ concentrations were similar in all farms (Table 4).

For the 'D. Maria' cultivar, cluster length and fresh weight of grapes were similar in all farms, but cluster weight and the number of grapes were larger at Alvisquer and Gomeira compared with the Pedras farm (Table 5). Rachis weight was greater at Alvisquer than at Pedras. Total soluble solids expressed as degree Brix were significantly greater in grapes from the Gomeira farm. For 'Cardinal' cultivar, the greatest values were measured at Alvisquer farm for all parameters except total soluble solids, which were similar in all farms.

For 'Cardinal' cultivar, the length of the cluster and the number of grapes were always positively correlated with $\mathrm{Mg}, \mathrm{Fe}, \mathrm{Mn}$ and $\mathrm{Cu}$ concentrations in the petioles. Calcium concentration in the petioles was also correlated with the number of grapes. The rachis weight was correlated with $\mathrm{Fe}$ and $\mathrm{Cu}$ concentrations. $\mathrm{Cu}$ was also correlated with cluster and grape weights (Table 6). For 'D. Maria' cultivar, the cluster and the raquis weights, and the number of grapes were negatively correlated with $\mathrm{P}$ concentrations in petioles. No other significant correlations could be established between nutrients in the petioles and clusters quality parameters.

\section{DISCUSSION}

The fertiliser recommendations for table grapes are based on the mineral composition of the leaf and petiole (INIA, 2000). If N, $\mathrm{P}$ and $\mathrm{K}$ are deficient, the amounts proposed are 80-100 N, 60-80 $\mathrm{P}_{2} \mathrm{O}_{5}$, and 90-120 $\mathrm{K}_{2} \mathrm{O} \mathrm{kg} \mathrm{ha}{ }^{-1}$. Similar values were proposed by other authors for wine grapes (e.g. Conradie and Myburgh, 2000).

For the cultivar 'Cardinal', the level of $\mathrm{P}$ and $\mathrm{K}$ applied seemed sufficient in all farms, and growth and yield depended on the content of other nutrients, namely $\mathrm{Mg}, \mathrm{Ca}$, $\mathrm{Fe}, \mathrm{Mn}$ and $\mathrm{Cu}$. This meant that some farms probably applied more nutrients than necessary. In particularly, at the Alvisquer farm the amount of $\mathrm{P}$ was more than that recommended.

The levels of $\mathrm{Mg}, \mathrm{Ca}, \mathrm{Fe}$ and $\mathrm{Mn}$ in petioles were greater in the Alvisquer farm than in the others and could explain the enhanced yield. In several vines of this cultivar, the weight of the clusters at Alvisquer even exceeded 1000g (data not shown).

For the 'D. Maria' cultivar this trend was not so clear since there were no differences between crops at Alvisquer and Gomeira, but values for the plant parameters measured at Alvisquer were also of a high level, which suggests that the fertiliser practice was very effective. However, other factors could have contributed for this result, namely larger irrigation volumes and a less severe pruning that would retain a larger endogenous nutrient pool for spring growth.

Consumer acceptance is better when fruits have large concentrations of soluble solids (Crisosto et al., 1994). At Gomeira farm, grapes of 'D. Maria' cultivar had the highest Brix value. This may be related to soil water availability since in this farm the amount of irrigation water was reduced during the maturation stage, probably causing a mild water stress. However, there were no practical consequences, since most buyers in the region do not consider this parameter as a reference for quality.

The poorest results were obtained at Pedras and Cascalhão farms. In the latter, the high carbonate content and soil $\mathrm{pH}$ (Table 2) led to iron chlorosis. This deficiency was not fully corrected, in spite of the foliar application of $\mathrm{Fe}$ and $\mathrm{B}$, thus leading to poor quality of the grapes as observed by Bavaresco and Poni (2003). At this farm (and also at Pedras), the nutrients stored in the vines were probably at deficient levels due to inadequate fertilisation of the vineyards during the juvenile stage. 
In conclusion, the nutritional status of the cultivar 'Cardinal', as evaluated by petiole analysis, influenced growth and yield, and differed between farms, while growth and yield of cultivar 'D. Maria' seemed to depend less on nutrient content.

\section{ACKNOWLEDGEMENTS}

We thank the farmers for their collaboration in this research. This work was supported by the POCTIA project 528/2003 and by the CDCTPV (I\&D Unity 1584).

\section{Literature Cited}

A.O.A.C. 1990. Association of Official Agricultural Chemists. Official Methods of Analysis. $12^{\text {th }}$ ed., Washington, D.C.

Bavaresco, L. and Poni, S. 2003. Effect of calcareous soil on photosynthesis rate, mineral nutrition, and source-sink ratio of table grape. J. Plant Nutr. 26: 2123-2135.

Conradie, W.J. and Myburgh, P.A. 2000. Fertigation of Vitis vinifera L. cv. Bukettraube/110 Richter on a sandy soil. S. Afr. J. Enol. Vitic. 21:40-47.

Crisosto, C.H., Smilanick, J.L., Dokoozlian, N.K. and Luvisi, D.A. 1994. Maintaining table grape postharvest quality for long distant markets. International symposium on table grape production, June 1994, Amer. Soc. Enology Vitic., 195-199.

G.P.P.A.A. 2001. Gabinete de Planeamento e Política Agro-Alimentar, Anuário Hortofrutícola, MADRP/GPPAA, Lisbon.

INIA 2000. Manual de Fertilização das Culturas. Instituto Nacional de Investigação Agrária, Lisbon.

Isaac, R.A. and Kerber, J.D. 1971. Atomic absorption and flame photometry: Techniques and uses in soil, plant, and water analysis, pp.17-37, In L.M. Walsh, ed. Instrumental methods for analysis of soils and plant tissue. Soil Science Society of America, Madison, WI.

Riehm, H. 1958. Die ammoniumlaktatessigsaure-methode zur bestimmung der leichtloslichen phosphosaure in karbonathaltigen boden. Agrochimica 3:49-65.

Walkley, A. and Black, I.A. 1934. An examination of the Degtjareff method for determining soil organic matter and a proposed modification of the chromic acid titration method. Soil Science 37:29-38.

\section{$\underline{\text { Tables }}$}

Table 1. Chemical analysis of composite soil samples collected at 20-50 cm between rows, on January 2002.

\begin{tabular}{lcccc}
\hline Farms & $\begin{array}{c}\text { Potassium } \\
\left(\mathrm{mg} \mathrm{K}_{2} \mathrm{O} \mathrm{kg}^{-1}\right)\end{array}$ & $\begin{array}{c}\text { Phosphorus } \\
\left(\mathrm{mg} \mathrm{P}_{2} \mathrm{O}_{5} \mathrm{~kg}^{-1}\right)\end{array}$ & $\begin{array}{c}\text { Organic } \\
\text { matter }(\%)\end{array}$ & $\mathbf{p H}\left(\mathrm{H}_{2} \mathbf{O}\right)$ \\
\hline \multicolumn{1}{c}{ cv. 'Cardinal' } & & & & \\
Alvisquer & 140 & 59 & - & 8.2 \\
Gomeira & 192 & 112 & 1.1 & 7.7 \\
Cascalhão & 143 & 160 & 1.1 & 8.1 \\
$\quad$ cv. 'D. Maria' & & & & \\
Alvisquer & 169 & 33 & - & 8.3 \\
Gomeira & 216 & 205 & 1.3 & 7.9 \\
Pedras & 179 & 158 & 0.8 & 8.3 \\
\hline
\end{tabular}


Table 2. Plantation details of the vineyards.

\begin{tabular}{lccc}
\hline Farms & Rootstocks & $\begin{array}{c}\text { Tree } \\
\text { spacing }\end{array}$ & $\begin{array}{c}\text { Plantation } \\
\text { year }\end{array}$ \\
\hline \multicolumn{1}{c}{ cv. 'Cardinal' } & R99 & $2.70 \times 1.20$ & 1991 \\
Alvisquer & R110 & $2.70 \times 1.10$ & 1991 \\
Gomeira & R99 & $3.00 \times 1.10$ & 1996 \\
Cascalhão & & & \\
$\quad$ cv. 'D. Maria' & & & 1991 \\
Alvisquer & SO4 & $2.70 \times 1.20$ & 1991 \\
Gomeira & 420A & $2.70 \times 1.10$ & 1994 \\
Pedras & R99 & $3.00 \times 1.10$ & \\
\hline
\end{tabular}

Table 3. Amounts of nutrients applied in each farm during 2002.

\begin{tabular}{lccccc}
\hline Farms & \multicolumn{3}{c}{$\begin{array}{c}\text { Nutrients applied }\left(\mathrm{kg} \mathrm{ha}^{-1}\right) \\
\mathbf{N}: \mathbf{P}_{\mathbf{2}} \mathbf{O}_{\mathbf{5}}: \mathbf{K}_{\mathbf{2}} \mathbf{O}\end{array}$} & NAF & $\begin{array}{c}\text { Fertigation } \\
\text { period }\end{array}$ \\
& \multicolumn{1}{c}{ Winter 2001} & Fertigation & Total & & \\
\hline \multicolumn{1}{c}{ cv. 'Cardinal' } & & & & & \\
Alvisquer & $60: 120: 60$ & $16: 22: 54$ & $76: 142: 104$ & 22 & April-June \\
Gomeira & $12: 16: 4$ & $9: 13: 15$ & $21: 29: 19$ & 5 & March-June \\
Cascalhão & $42: 60: 60$ & $14: 24: 41$ & $56: 84: 101$ & 13 & March-June \\
$\quad$ cv. 'D. Maria' & & & & \\
Alvisquer & $60: 120: 60$ & $14: 8: 51$ & $74: 128: 111$ & 20 & April-June \\
Gomeira & $12: 16: 4$ & $11: 13: 17$ & $23: 29: 21$ & 5 & March-June \\
Pedras & $42: 60: 60$ & $25: 59: 73$ & $67: 119: 113$ & 16 & March-July \\
\hline
\end{tabular}

NAF - number of applications by fertigation.

Table 4. Dry weights (g) and nutrient concentrations in the petiole of mature leaves collected at the end of experiment (July 4 for cv. 'Cardinal' and August $13 \mathrm{for} \mathrm{cv}$. 'D. Maria'). Each value is the mean of three replicates and each replicate is the sum of 6 petioles per farm.

\begin{tabular}{|c|c|c|c|c|c|c|c|c|c|}
\hline \multirow{2}{*}{ Farms } & \multirow{2}{*}{ DW } & \multicolumn{4}{|c|}{ Macronutrients $\left(\mathrm{g} \mathrm{kg}^{-1} \mathrm{DW}\right)$} & \multicolumn{4}{|c|}{ Micronutrients ( $\left.\mathrm{mg} \mathrm{kg}^{-1} \mathrm{DW}\right)$} \\
\hline & & $\mathrm{P}$ & $\mathrm{K}$ & $\mathrm{Mg}$ & $\mathrm{Ca}$ & $\mathrm{Fe}$ & $\mathrm{Mn}$ & $\mathrm{Zn}$ & $\mathrm{Cu}$ \\
\hline \multicolumn{10}{|c|}{ cv. 'Cardinal' } \\
\hline Alvisquer & $2.5 \mathrm{a}$ & $2.5 \mathrm{c}$ & $11 \mathrm{ab}$ & $11.3 \mathrm{a}$ & $36 \mathrm{a}$ & $95 \mathrm{a}$ & $94 \mathrm{a}$ & $34 \mathrm{a}$ & $5 \mathrm{a}$ \\
\hline Gomeira & $2.6 \mathrm{a}$ & $5.3 \mathrm{a}$ & $8 \mathrm{~b}$ & $9.3 \mathrm{~b}$ & $31 \mathrm{~b}$ & $54 \mathrm{~b}$ & $28 \mathrm{~b}$ & $38 \mathrm{a}$ & $3 a$ \\
\hline Cascalhao & $2.5 \mathrm{a}$ & $3.3 \mathrm{~b}$ & $13 \mathrm{a}$ & $8.7 \mathrm{c}$ & $19 \mathrm{~b}$ & $58 \mathrm{~b}$ & $11 \mathrm{~b}$ & $33 \mathrm{a}$ & $3 \mathrm{a}$ \\
\hline \multicolumn{10}{|c|}{ cv. 'D. Maria' } \\
\hline Alvisquer & $1.6 \mathrm{~b}$ & $2.5 \mathrm{~b}$ & $11 \mathrm{a}$ & $10.3 \mathrm{~b}$ & $47 \mathrm{a}$ & $70 \mathrm{~b}$ & $73 \mathrm{a}$ & $73 \mathrm{a}$ & $3 \mathrm{a}$ \\
\hline Gomeira & $2.1 \mathrm{a}$ & $3.6 \mathrm{ab}$ & $9 \mathrm{a}$ & $8.3 \mathrm{~b}$ & $49 \mathrm{a}$ & $84 \mathrm{a}$ & $10 \mathrm{c}$ & $52 \mathrm{~b}$ & $3 \mathrm{a}$ \\
\hline Pedras & $1.6 \mathrm{~b}$ & $4.6 \mathrm{a}$ & $8 \mathrm{a}$ & $17.3 \mathrm{a}$ & $40 \mathrm{~b}$ & $72 \mathrm{ab}$ & $24 \mathrm{~b}$ & $59 \mathrm{ab}$ & $4 \mathrm{a}$ \\
\hline
\end{tabular}


Table 5. Effect of fertiliser practices on quality parameters of clusters collected at the end of experiment (July 4 for cv. 'Cardinal' and August 13 for cv. 'D. Maria'). Each value is the mean of 15 replicates.

\begin{tabular}{lcccccc}
\hline Farms & $\begin{array}{c}\text { Cluster } \\
\text { length } \\
(\mathrm{cm})\end{array}$ & $\begin{array}{c}\text { Cluster } \\
\text { weight } \\
(\mathrm{g})\end{array}$ & $\begin{array}{c}\text { Rachis } \\
\text { weight } \\
(\mathrm{g})\end{array}$ & $\begin{array}{c}\text { Grapes } \\
\text { weight } \\
(\mathrm{g})\end{array}$ & $\begin{array}{c}\text { Number of } \\
\text { grapes }\end{array}$ & $\begin{array}{c}\text { Total soluble } \\
\text { solids }\left({ }^{\circ} \mathrm{Brix}\right)\end{array}$ \\
\hline \multicolumn{2}{c}{$\mathrm{cv}$ 'Cardinal' } & & & & & \\
Alvisquer & $25.0 \mathrm{a}$ & $599.8 \mathrm{a}$ & $28.8 \mathrm{a}$ & $563.7 \mathrm{a}$ & $129.8 \mathrm{a}$ & $16.8 \mathrm{a}$ \\
Gomeira & $18.0 \mathrm{~b}$ & $381.2 \mathrm{~b}$ & $15.1 \mathrm{~b}$ & $377.5 \mathrm{~b}$ & $87.7 \mathrm{~b}$ & $16.7 \mathrm{a}$ \\
Cascalhão & $18.9 \mathrm{~b}$ & $307.8 \mathrm{~b}$ & $17.1 \mathrm{~b}$ & $289.3 \mathrm{~b}$ & $72.9 \mathrm{~b}$ & $16.6 \mathrm{a}$ \\
\multicolumn{1}{c}{ cv. 'D. Maria' } & & & & & \\
Alvisquer & $28.1 \mathrm{a}$ & $833.9 \mathrm{a}$ & $14.7 \mathrm{a}$ & $668.0 \mathrm{a}$ & $96.5 \mathrm{a}$ & $15.8 \mathrm{~b}$ \\
Gomeira & $27.7 \mathrm{a}$ & $764.6 \mathrm{a}$ & $11.8 \mathrm{ab}$ & $625.9 \mathrm{a}$ & $84.2 \mathrm{a}$ & $21.3 \mathrm{a}$ \\
Pedras & $25.7 \mathrm{a}$ & $516.5 \mathrm{~b}$ & $8.4 \mathrm{~b}$ & $448.2 \mathrm{a}$ & $60.0 \mathrm{~b}$ & $17.2 \mathrm{~b}$ \\
\hline
\end{tabular}

For each cultivar, means in a column followed by the same letter are not significantly different at $\mathrm{p}<0.05$ (Duncan test).

Table 6. Correlation coefficients (r) between nutrient concentrations in petioles and quality parameters of clusters collected at the end of experiment (July 4 for cv. 'Cardinal' and August 13 for cv. 'D. Maria').

\begin{tabular}{lcccccccc}
\hline & $\mathbf{P}$ & $\mathbf{K}$ & $\mathbf{M g}$ & $\mathbf{C a}$ & $\mathbf{F e}$ & $\mathbf{M n}$ & $\mathbf{Z n}$ & $\mathbf{C u}$ \\
\hline \multicolumn{1}{c}{ cv. 'Cardinal' } & & & & & & & & \\
Cluster length & -0.66 & 0.18 & $0.77^{*}$ & 0.60 & $0.88^{* *}$ & $0.78^{*}$ & -0.18 & $0.69^{*}$ \\
Cluster weight & -0.32 & 0.11 & 0.50 & 0.64 & 0.57 & 0.56 & -0.27 & $0.83^{* *}$ \\
Total soluble solids & 0.27 & -0.44 & 0.23 & 0.11 & 0.07 & 0.04 & 0.47 & -0.38 \\
Number of grapes & -0.37 & -0.03 & $0.75^{*}$ & $0.75^{*}$ & $0.79^{*}$ & $0.74 *$ & -0.03 & $0.71^{*}$ \\
Grapes weight & -0.26 & 0.09 & 0.49 & 0.64 & 0.55 & 0.53 & -0.23 & $0.81^{* *}$ \\
Raquis weight & -0.66 & 0.29 & 0.56 & 0.55 & $0.69 *$ & 0.65 & -0.32 & $0.89^{* *}$ \\
\multicolumn{1}{c}{ cv. 'D. Maria' } & & & & & & & & \\
Cluster length & -0.44 & 0.38 & -0.40 & 0.31 & 0.11 & 0.34 & 0.57 & 0.37 \\
Cluster weight & $-0.69^{*}$ & 0.45 & -0.62 & 0.53 & 0.06 & 0.42 & 0.49 & -0.04 \\
Total soluble solids & 0.36 & 0.13 & -0.31 & 0.00 & 0.07 & -0.51 & -0.33 & -0.03 \\
Number of grapes & $-0.75^{*}$ & 0.58 & -0.64 & 0.54 & 0.19 & 0.54 & 0.52 & 0.00 \\
Grapes weight & -0.62 & 0.27 & -0.56 & 0.47 & 0.01 & 0.33 & 0.32 & -0.01 \\
Raquis weight & $-0.84^{* *}$ & 0.38 & -0.63 & 0.55 & -0.11 & 0.63 & 0.57 & -0.04 \\
\hline Significant at $\mathrm{p}<0.05(*)$ and at $\mathrm{p}<0.01(* *)$. & & & & &
\end{tabular}




\section{Figures}
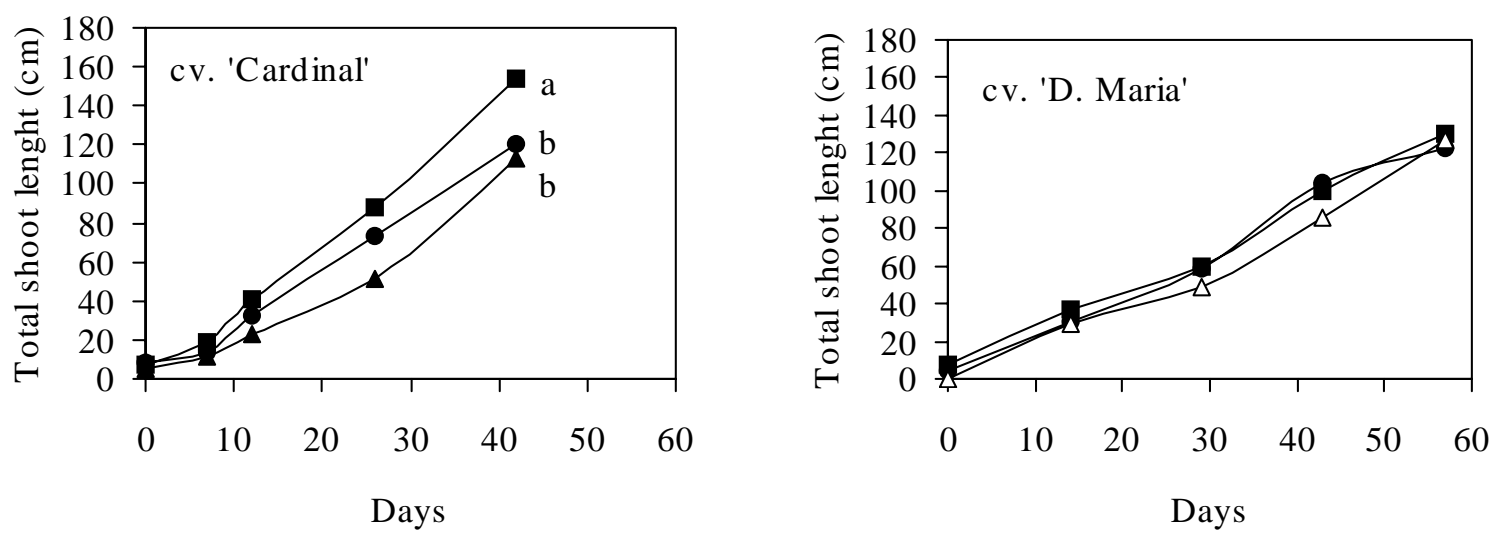

$\multimap$ Alvisquer farm $\neg$ Cascalhão farm $\rightarrow$ Gomeira farm $\neg-$ Pedras farm

Fig. 1. Total shoot length $(\mathrm{cm})$ for each cultivar throughout the growing season. Statistical analysis is presented only for the last date. For cv. 'Cardinal', means followed by the same letter are not significantly different at $\mathrm{p}<0.05$ (Duncan test). For cv. 'D. Maria' no significant differences were observed. 